\title{
PEMANFAATAN CLOUD GIS UNTUK PEMETAAN SUMBER DAYA ALAM INDONESIA DI PT. GEOTAMA ENERGI Agus Sasmito A ${ }^{(1)}$, Budi Santosa ${ }^{(2)}$, Dessyanto Boedi $P^{(3)}$ \\ Teknik Informatika, Fakultas Teknologi Industri \\ Universitas Pembangunan Nasional "Veteran" Yogyakarta \\ JIn. Babarsari 2, Tambakbayan Yogyakarta \\ e-mail : sasmito_skom@yahoo.com
}

\begin{abstract}
Natural resource mapping using information technology will process spatial data into more meaningful information and useful for the recipient. The conversion of natural resource data into a digital-based geographic information system being developed. Map of natural resources include spatial map of mineral deposits, oil and gas in Indonesia. The map is equipped with non-spatial data, such as the name of the location of natural resources, the amount of content, exploration history, state or corporate tenants, as well as the amount of production per unit time. This natural resource data will yield information such as maps digitally natural resources and complementary attributes.

The methodology used in the development of an integrated information system are SWOT (Strong, weekness, Opportunity and Threat) Analysis and SDLC (System Development Life Cycle). The design use CASE Tools (Computer Aided Software Engineering). The system will be implemented by the architecture of cloud computing, cloud is used as a place to store the data, applications, and others to facilitate the exploration of natural resources in Indonesia.

The results of the research is a prototype of GIS application for showing the locations of natural resources in Indonesia. Research can be useful for documenting the location of these resources for the parties concerned, especially the PT. Geotama Energy.
\end{abstract}

\section{Key Word: Mapping, Cloud Computing, GIS}

\section{Abstrak}

Pemetaan sumber daya alam menggunakan teknologi informasi akan mempermudah pengolahan data spasial menjadi informasi yang lebih bermakna dan bermanfaat bagi penerimanya. Pengubahan data sumber daya alam menjadi berbasis digital dan berorientasi pada sistem informasi geografis terus dikembangkan. Perkembangan mengalami suatu kendala jika peta digital sulit didistribusikan kepada semua stake holder dan akhirnya akan mempersulit komunikasi data.

Peta sumber daya alam meliputi peta spasial kandungan mineral, gas dan minyak bumi di Indonesia. Peta tersebut dilengkapi dengan data non spasial, misalnya nama lokasi sumber daya alam, jumlah kandungan, riwayat eksplorasi, negara atau perusahaan penggarap, serta jumlah produksi per satuan waktu. Data sumber daya alam ini akan menghasilkan informasi berupa peta sumber daya alam secara digital dan atribut pelengkapnya.

Metodologi yang akan digunakan dalam pengembangan sistem informasi terpadu tersebut adalah SWOT (Strong, Weekness, Opportunity and Threat) Analysis dan SDLC (System Development Life Cycle). Dalam Perancangan digunakan CASE Tools (Computer Aided Software Engineering) berorientasi objek. Sistem akan diimplementasikan dengan arsitektur cloud computing, dimana pada sistem tersebut media internet cloud digunakan sebagai tempat menyimpan data, aplikasi, dan lainnya sehingga memudahkan dalam eksplorasi sumber daya alam Indonesia.

Hasil penelitian berupa sarana berbasis GIS untuk memperlihatkan lokasi-lokasi sumber daya alam di Indonesia. Penelitian dapat bermanfaat untuk dokumentasi lokasi sumberdaya tersebut bagi pihak-pihak yang berkepentingan, terutama PT. Geotama Energy.

Kata Kunci: Pemetaan, Cloud Computing, GIS

\section{PENDAhULUAN}

Ruang lingkup penelitian ini adalah merancang kerangka arsitektur atau model sistem informasi geografis berbasis web untuk pemetaan sumber daya alam. Sumber daya alam dibatasi pada sumber daya alam mineral, gas dan minyak bumi, berikut sarana-prasarananya. 
Sistem tersebut bersifat interaktif dan dinamis dan akan digunakan untuk membantu proses pengelolaaan data sumber daya alam di Indonesia. Data tersebut diolah dan diproses menjadi peta digital sumber daya alam dalam bentuk Sistem Informasi Geografis berbentuk web interaktif dan dinamis yang bermanfaat bagi semua pihak yang mengelola dan pemanfaatan sumber daya alam di Indonesia

Pijakan awal dari penelitian ini adalah dinamika lingkungan strategis berupa revolusi teknologi informasi yang melahirkan sistem informasi geografis (GIS) berbasis web interaktif dan dinamis. Sistem ini nantinya diharapkan mampu memberikan sumbangan bagi semua pihak dalam rangka memudahkan tersedianya informasi sumber daya alam di Indonesia berbentuk sistem informasi geografis dalam upaya melestarikan, meningkatkan produksi dan eksplorasi demi kemakmuran rakyat. Jika dapat diwujudkan maka sistem informasi ini akan memetakan kekayaan alam seperti kandungan minyak, kandungan gas alam, kandungan mineral, titik-titik distribusi bahan tambang dan sebagainya. Informasi yang ada akan memudahkan semua stake holder mengakses sarana prasarana dan sumberdaya eksplorasi pada lokasi-lokasi yang berprioritas tinggi. Lokasi berprioritas adalah lokasi yang secara ekonomi memberikan lebih banyak keuntungan jika dilakukan eksplorasi. Peta digital yang dipakai menggunakan Google map, yang merupakan peta geografis yang cukup akurat dan merupakan terobosan baru karena berbasis cloud computing sehingga mudah di akses di mana saja.

Ruang lingkup penelitian ini adalah merancang kerangka arsitektur atau model sistem informasi geografis berbasis web untuk pemetaan sumber daya alam yang dibatasi pada sumber daya alam mineral, gas dan minyak bumi, berikut sarana-prasarananya. Sistem tersebut bersifat interaktif dan dinamis dan akan digunakan untuk membantu proses pengelolaaan data sumber daya alam di Indonesia. Kemudian data tersebut diolah dan diproses menjadi informasi pemetaan sumber daya alam yang bermanfaat bagi semua pihak dalam rangka pemanfaatan sumber daya alam di Indonesia.

Berdasarkan uraian latar belakang permasalahan yang telah dipaparkan di atas, maka pada penelitian ini akan membahas bagaimana menyusun sistem informasi sumber daya alam Indonesia berbasis teknologi informasi dan komunikasi (TIK) dalam bentuk sistem informasi geografis berbasis web interaktif dan dinamis.

Tujuan penelitian adalah menghasilkan prototype Sistem Informasi Geografis yang bersifat interaktif dan dinamis dan prototype sistem ini merupakan implementasi dari dokumen perencanaan dan pengembangan sistem tersebut.

Hasil penelitian akan bermanfaat bagi pihak-pihak terkait antara lain bagi PT. Geotama Energy dan dunia akademik. PT. Geotama Energy akan mendapatkan sarana bantu untuk memetakan sumber daya alam. Pihak akademik mendapatkan sarana untuk implementasi pengetahuan dalam bentuk nyata.

\section{TINJAUAN PUSTAKA}

\subsection{Definisi Sistem Informasi Geografis}

Sistem Informasi Geografi (SIG) merupakan sistem kompleks yang biasanya terintegrasi dengan lingkungan sistem-sistem komputer yang lain di tingkat fungsional dan jaringan. Sistem SIG terdiri dari beberapa komponen (Prahasta,2001):
a. Perangkat Keras
b. Perangkat Lunak
c. Data dan Informasi Geografi
d. Manajemen

\subsection{Penelitian Sebelumnya}

Penelitian yang telah dilakukan sebelumnya telah menghasilkan suatu aplikasi SIG berbasis web untuk pemetaan layanan kesehatan masyarakat (Santosa, 2011). Aplikasi tersebut sebatas memetakan layanan kesehatan yang ada di Yogyakarta dan antar Puskesmas yang ada belum terintegrasi secara online. Pada penelitian ini akan dibangun suatu Sistem Informasi Terpadu yang berbasis Web GIS untuk pemetaan sumber daya alam Indonesia dengan memanfaatkan teknologi cloud computing.

\section{METODOLOGI PENELITIAN}

Metodologi yang akan digunakan pada penelitian ini antara lain : SWOT Analysis, SDLC (System Development Life Cycle) yang meliputi tahap Analysis, Design, Implementation, 
Testing dan Maintenance (Gambar 1), (Pressman, 2003). Penelitian dimulai dengan melakukan SWOT Analysis terhadap data sumber daya alam Indonesia. Berdasarkan hasil SWOT Analysis, data-data yang diperoleh digunakan sebagai acuan didalam membangun suatu Sistem Informasi Geografis untuk pemetaan sumber daya alam Indonesia. Pembangunan sistem ini menggunakan metode SDLC.

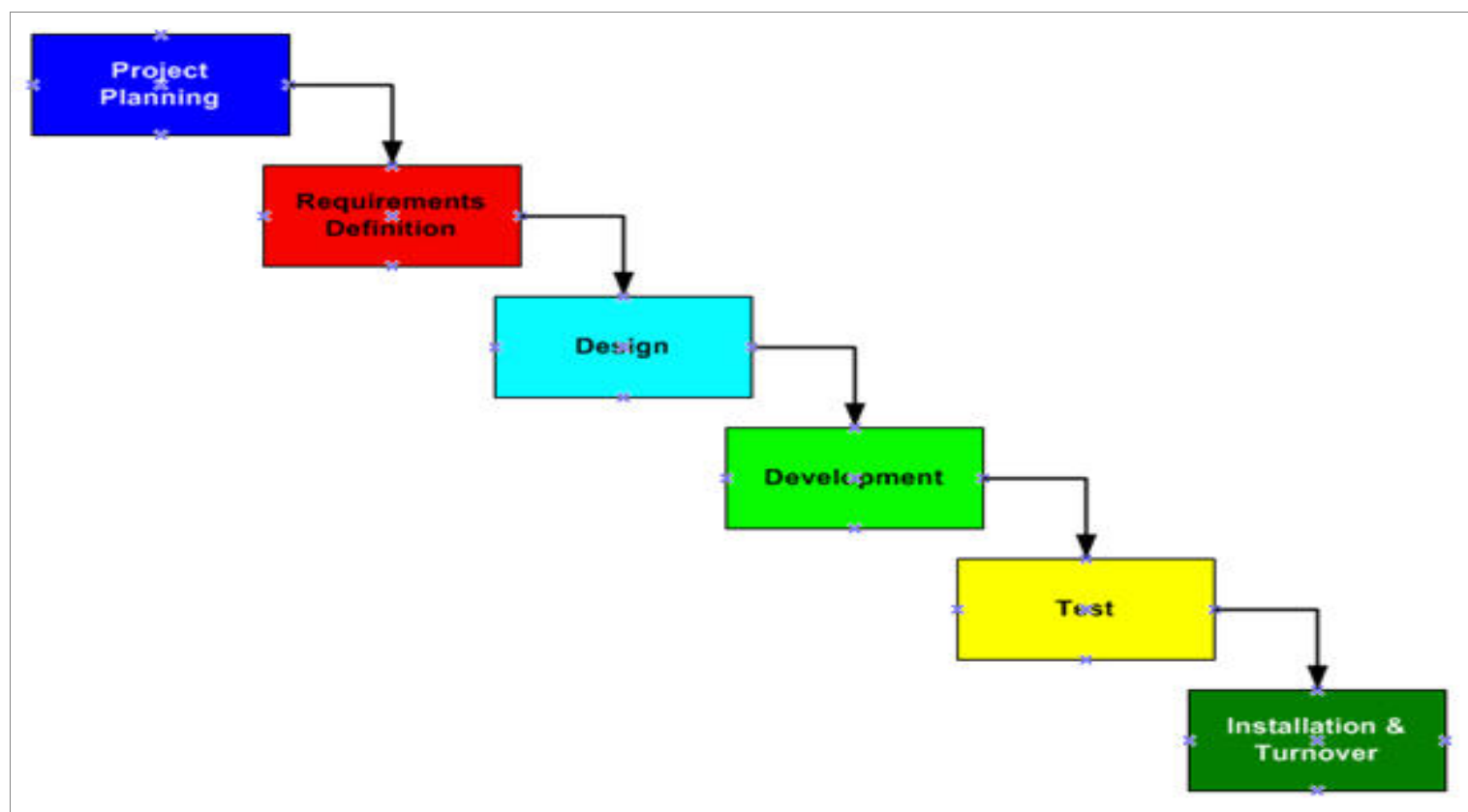

Gambar 1. Metode SDLC model air terjun (Pressman, 2003)

Tahap pertama melakukan analisa kebutuhan dari sistem yang akan dibuat. Tahap kedua membuat rancangan terhadap analisa yang telah dilakukan, meliputi rancangan logika dan rancangan antarmuka sistem. Tahap ketiga adalah implementasi yaitu, mewujudkan sistem dengan melakukan pembuatan program (coding). Bahasa pemrograman yang digunakan adalah PhP, MySQL, serta MapServer untuk menampilkan sistem melalui internet. Seluruhnya merupakan paket aplikasi yang open source. Tahap keempat melakukan testing terhadap sistem yang telah dibuat untuk menguji apakah hasil penelitian sudah benar sesuai dengan yang diharapkan. Tahapan terakhir adalah pemeliharaan, yaitu operasional dari sistem yang dihasilkan, bila ada kerusakan dapat segera dilakukan perbaikan.

\subsection{Analisis Kebutuhan Sistem}

Ruang lingkup penelitian ini adalah perancangan dan pembuatan sistem informasi sumber daya alam terpadu dalam bentuk sistem informasi geografis Analisis Kebutuhan pengunjung. Kebutuhan pengunjung meliputi apa saja yang dibutuhkan oleh pengunjung pada SIG-SDA ini berupa:

a. Tampilan peta sumber daya alam Indonesia.

b. Tampilan informasi dasar dari setiap sumber daya alam tersebut.

Kebutuhan administrator sistem meliputi apa saja yang dibutuhkan oleh admin pada SIG-SDA ini berupa:

a. Melakukan proses login terhadap sistem.

b. Tampilan peta SDA di Indonesia.

c. Tampilan informasi dasar dan informasi SDA masing-masing lokasi.

d. Mengolah data informasi dasar.

e. Mengolah data informasi SDA. 


\subsection{Perancangan Sistem}

Tahapan perancangan sistem adalah tahapan mengidentifikasi kebutuhan fungsional dalam mempersiapkan rancang bangun implementasi yang bertujuan untuk merancang dan mendesain sistem dalam memenuhi kebutuhan pengguna sistem. Perancangan sistem terdiri dari :

1. Perancangan Data Flow Diagram (DFD) sebagaimana pada Gambar 2. dan Gambar 3.

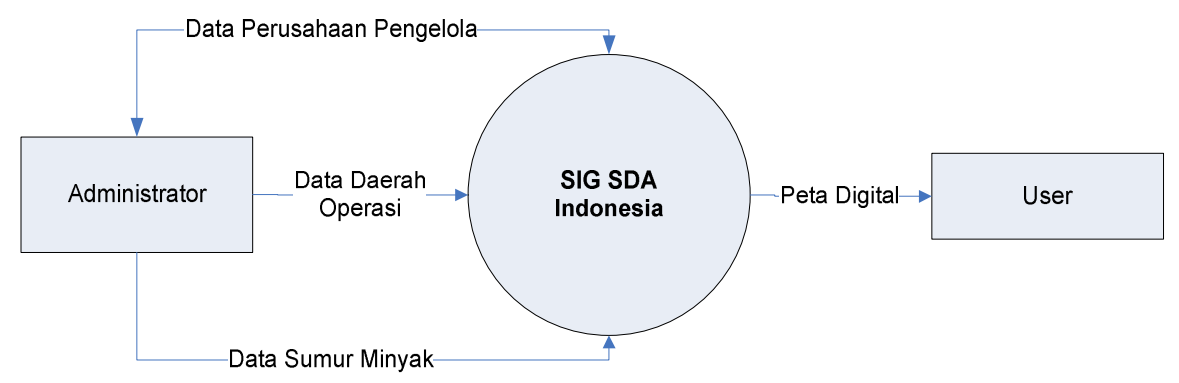

Gambar 2. DFD Level 0

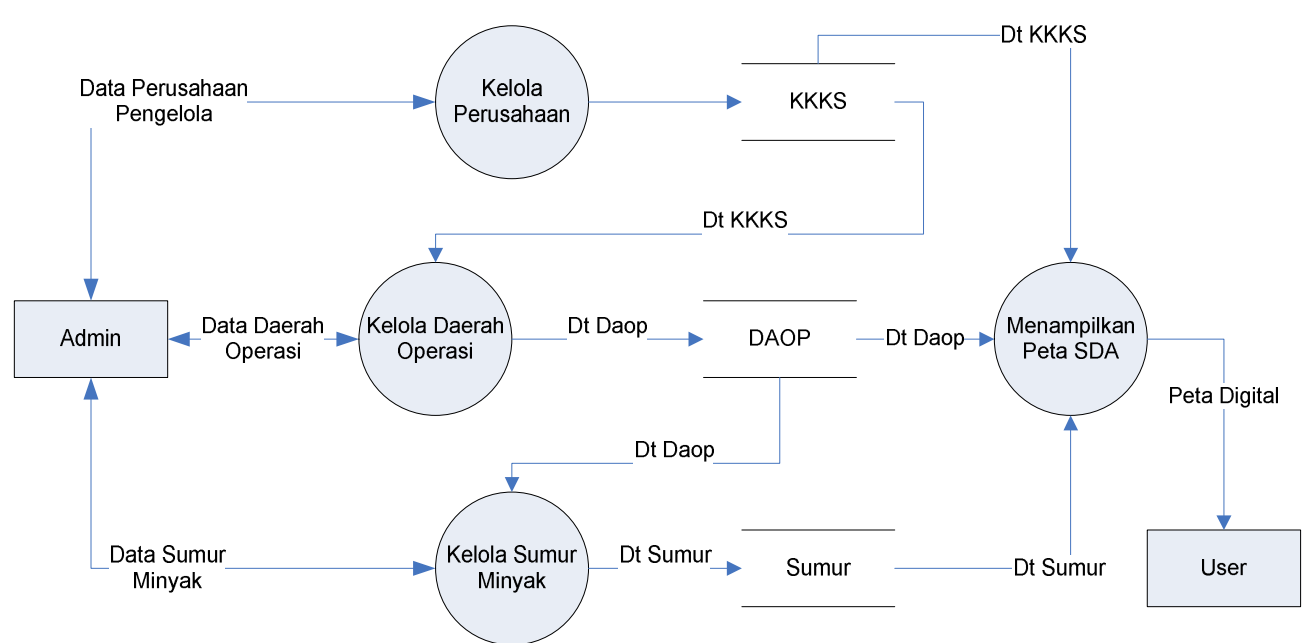

Gambar 3. DFD Level 1

2. Perancangan database terdiri dari perancangan Entity Relationship Diagram (ERD) dan perancangan tabel.

Dalam Entity Relationship Diagram (ERD) terdapat hubungan dan relasi antar entitas yang digunakan untuk membangun SIG SDA ini. ERD untuk perancangan database dalam SIG SDA Indonesia dapat dilihat pada gambar 4.

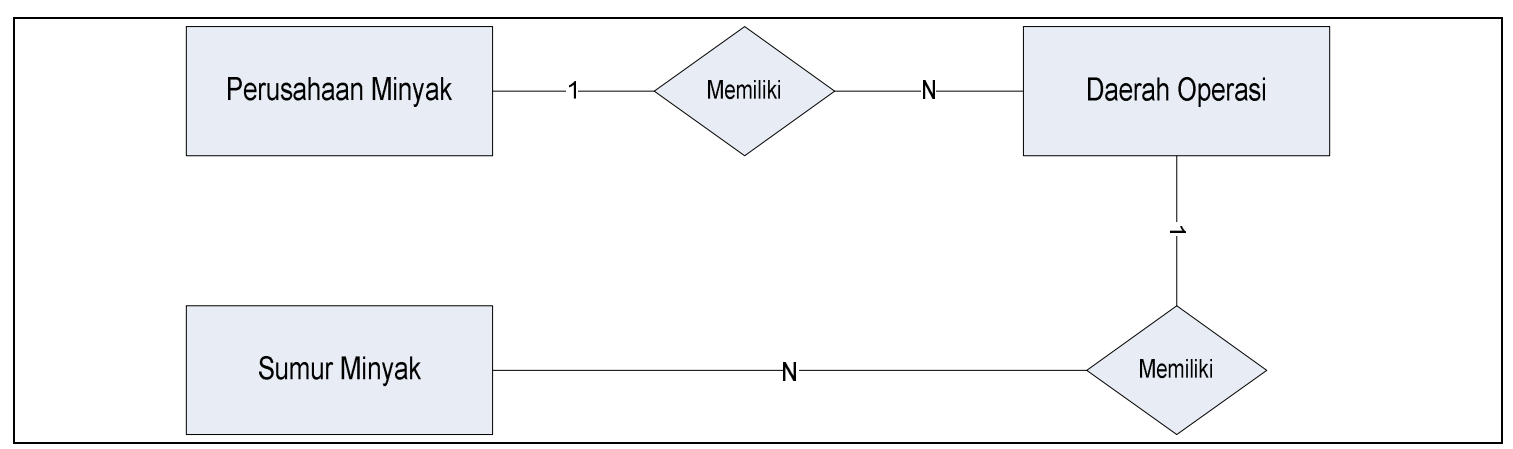

Gambar 4. Entity Relationship Diagram (ERD) 


\section{Perancangan Tabel}

Tabel database SIG (Sistem Informasi Geograsi) SDA di Indonesia adalah sebagai berikut : a. Tabel admin

Berikut tabel admin, tabel ini digunakan untuk menyimpan data admin. Tabel ini memiliki primary key id_admin. Field-field dapat dilihat pada Tabel 1.

Tabel 1 Tabel admin

\begin{tabular}{|l|l|l|l|}
\hline Field & Tipe Data & Constrain & Keterangan \\
\hline Id_admin & int(11) & Not Null, Primary Key & data Id admin \\
\hline username & varchar(25) & Not Null & data username \\
\hline password & varchar(25) & Not Null & data password \\
\hline
\end{tabular}

b. Tabel perusahaan

Berikut tabel perusahaan tabel ini digunakan untuk menyimpan data perusahaan pengelola SDA. Field-field dapat dilihat pada Tabel 2.

Tabel 2 Tabel Perusahaan

\begin{tabular}{|l|l|l|l|}
\hline Field & Tipe Data & Constrain & Keterangan \\
\hline Id_kkks & int(11) & Not Null, Primary Key & id perusahaan \\
\hline NamaPerusahaan & Varchar (100) & Not Null & Nama perusahaan \\
\hline PresidenDirektur & Varchar (100) & Not Null & Presiden direktur \\
\hline Alamat & Varchar (255) & & Alamat \\
\hline
\end{tabular}

c. Tabel Daerah Operasi

Tabel ini digunakan untuk mencatat daerah operasi setiap perusahaan pengelola SDA. Tabel ini memiliki primary key id_daop. Field-field dapat dilihat pada Tabel 3.

Tabel 3. Tabel Daerah Operasi

\begin{tabular}{|l|l|l|l|}
\hline Field & Tipe Data & Constrain & Keterangan \\
\hline id_daop & int(11) & $\begin{array}{l}\text { Not Null, } \\
\text { Primary Key }\end{array}$ & Id daerah operasi \\
\hline Id_kkks & int(11) & Not Null & id perusahaan \\
\hline Nama_daop & Varchar (100) & Not Null & Nama daerah operasi \\
\hline Luas_daerah & Float & Not Null & Luas daerah operasi \\
\hline Kapasitas_produksi & Float & Not Null & $\begin{array}{l}\text { Kapasitas produksi } \\
\text { daerah operasi }\end{array}$ \\
\hline Wilayah & Varchar (100) & Not Null & Wilayah daerah operasi \\
\hline
\end{tabular}

d. Tabel Sumur Minyak

Tabel ini digunakan untuk mencatat data sumur minyak berikut posisinya secara geografis.

Field-field dapat dilihat pada Tabel 4

Tabel 4. Tabel Sumur Minyak

\begin{tabular}{|l|l|l|l|}
\hline Field & Tipe Data & Constrain & Keterangan \\
\hline Id_sumur & Int(11) & Not Null, Primary Key & Nomor id sumur \\
\hline id_daop & int(11) & Not Null & Untuk mengisi id wilayah \\
\hline nama_sumur & varchar(25) & Not Null & Untuk mengisi nama wilayah \\
\hline Lapangan & varchar(25) & & Nama lapangan minyak \\
\hline Latitude & Float & Not Null & Lokasi latitude \\
\hline Longitude & Float & Not Null & Lokasi longitude \\
\hline
\end{tabular}

\subsection{Perancangan Relasi Antar Tabel}

Relasi Antar Tabel (RAT) yang berguna sebagai gambaran hubungan antar tabel dimana tabel yang mempunyai relasi dapat saling berhubungan, seperti dapat dilihat pada gambar 5 . 


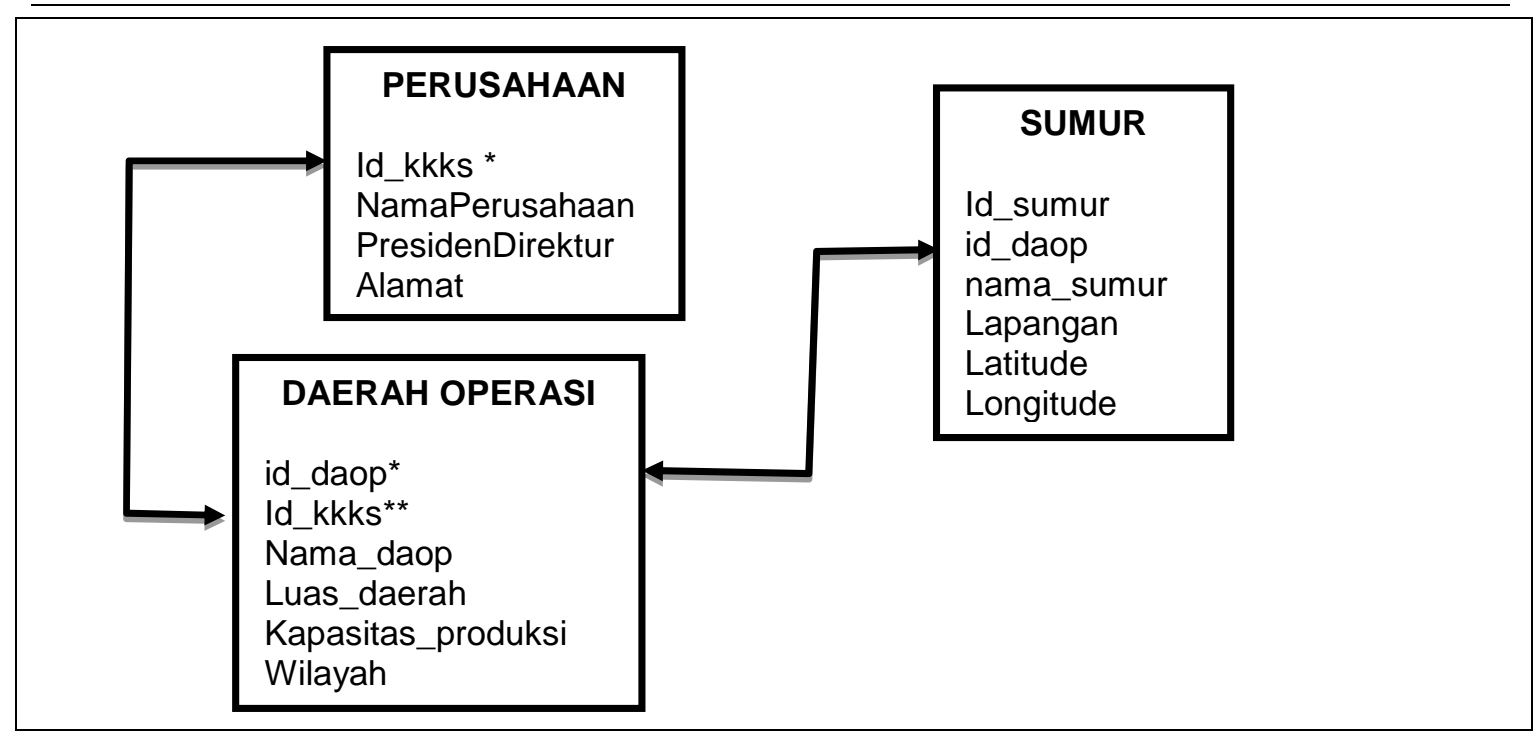

\section{Gambar 5. Relasi Antar Tabel (RAT)}

Pada model data relasional hubungan antar tabel direlasikan dengan kunci utama (primary key) dan kunci (foreign key) dari masing-masing tabel. Pada tabel diatas primary key ditandai dengan huruf tebal dan garis bawah, sedangkan pada foreign key ditandai dengan bintang.

\section{IMPLEMENTASI DAN PEMBAHASAN}

Perangkat lunak yang digunakan dalam implementasi aplikasi ini adalah sebagai berikut :

a. Google Maps API

b. PHP/Map Scripct

c. MySQL

d. Windows 7 Premium

Google Map merupakan peta digital yang disediakan Google untuk dipakai oleh pengguna internet secara umum. Peta tersebut merupakan layanan cloud computing dimana pengguna tidak perlu memikirkan pembuatan, instalasi, dan pemeliharaan aplikasi peta tersebut, tetapi cukup menggunakannya saja dengan memanfaatkan API yang disediakan Google. Pemanfaatan peta menggunakan Google Map menunjukkan hasil yang baik dimana peta dapat diimplementasikan secara sempurna serta tepat posisi-posisinya berdasarkan koordniat latitude dan longitude.

Hasil dari proses implementasi berupa tampilan form atau interface aplikasi beserta modul-modul program pembentuknya. Pada aplikasi ini terdapat beberapa form yang digunakan oleh admin dan pengunjung. Halaman utama pengunjung pada Gambar 6 merupakan halaman home ketika program dijalankan. Pada halaman ini, pengunjung akan mendapati tampilan gambaran umum Peta SDA Indonesia 


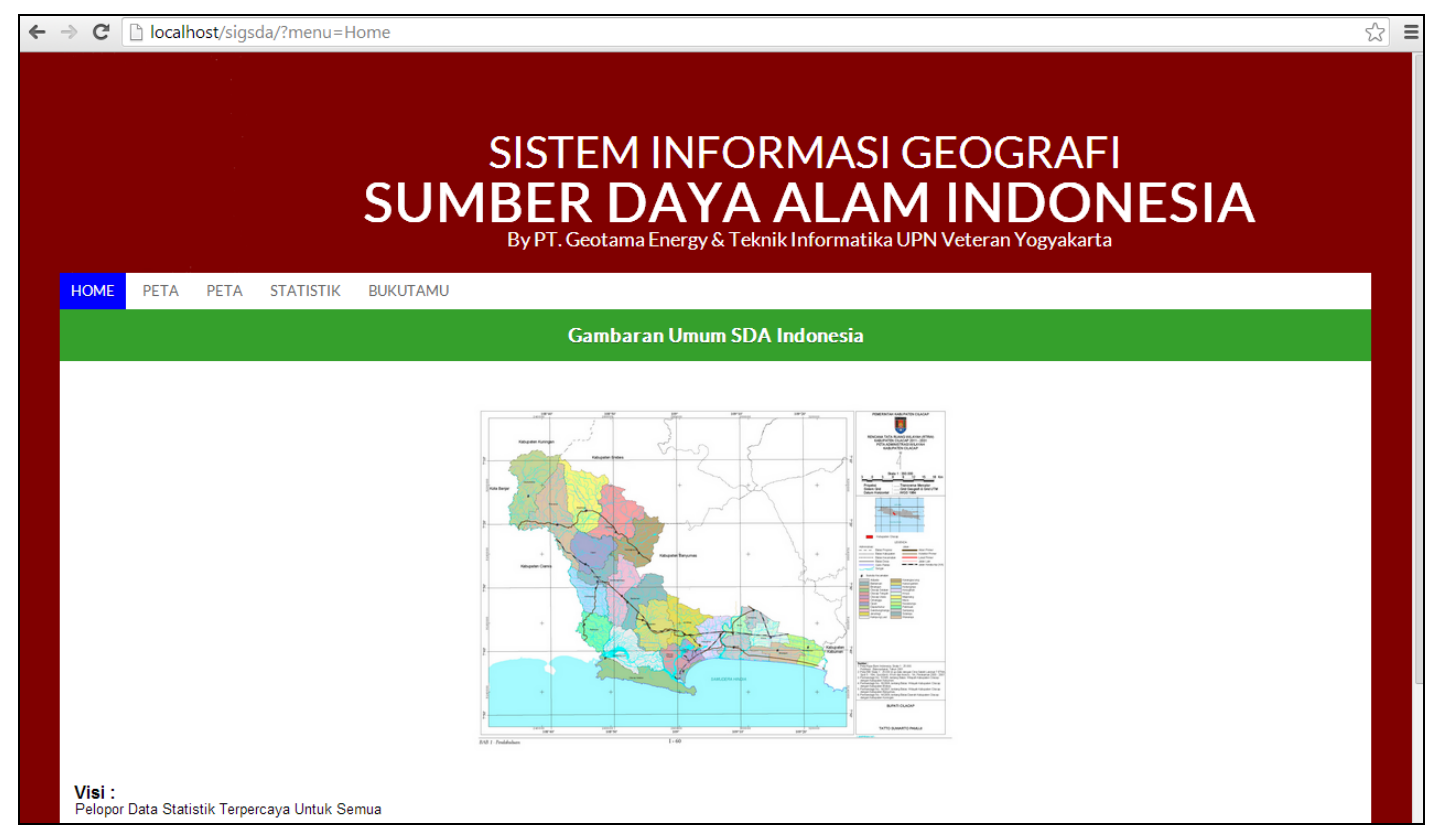

Gambar 6. Halaman Pengunjung

Halaman pada Gambar 7 merupakan halaman peta pengunjung. Pada halaman ini, pengunjung akan mendapati tampilan peta Indonesia. Sumber daya alam ditunjukkan dengan memilih daerah operasi dalam pilihan di pojok kiri atas dan daerah operasi akan tampil dalam bentuk peta berikut posisi-posisi sumur minyak yang sedang di esplorasi.

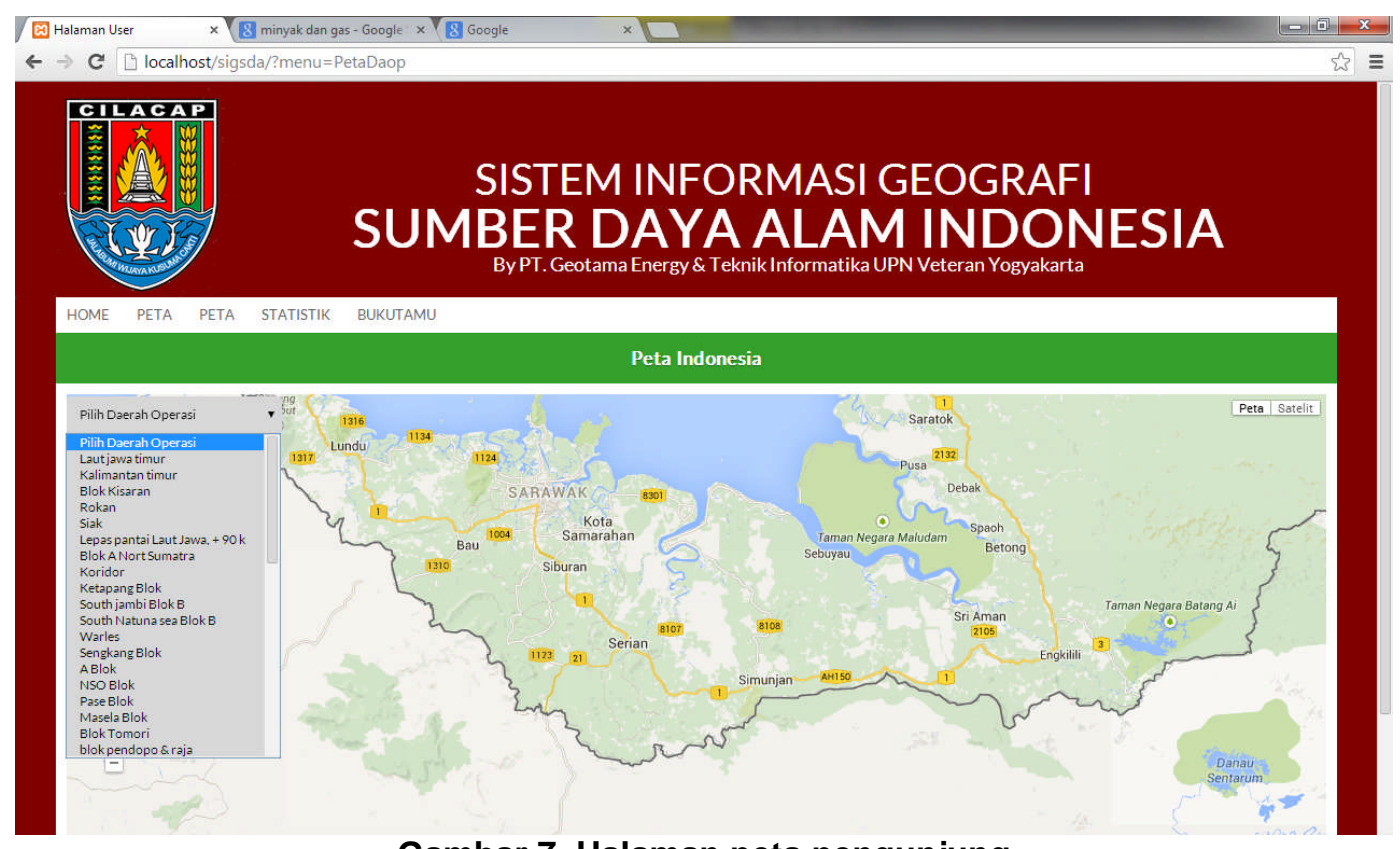

Gambar 7. Halaman peta pengunjung

Prinsip dasarnya adalah bagaimana memetakan data spasial di database (terutama dari tabel sumur) ke peta digital, sehingga dalam peta digital dapat ditampilkan titik-titik pemboran minyak bumi secara jelas. Uji coba zoooming pada peta juga menunjukkan bahwa posisi objek tidak mengalami pergeseran dan tetap menempati koordinat yang diinginkan sehingga validitas tetap terjamin. 


\section{KESIMPULAN}

Berdasarkan hasil penelitian tersebut diatas diperoleh kesimpulan sebagai berikut.

a. Sistem informasi geografi pemetaan sumber daya alam Indonesia telah berhasil dibangun menggunakan Google Map dan pemrograman web berbasis PHP dan mysql.

b. Sistem tersebut dapat membantu menampilkan peta eksplorasi sumber daya alam khususnya minyak bumi berikut nama pengelolanya dan daerah operasinya.

c. Sistem dilengkapi informasi kapasitas produksi, wilayah dan luas daerah operasi.

\section{SARAN}

Mengingat data pemetaan sumber daya alam diatas belum lengkap maka dapat ditambahkan data eksplotasi bahan tambang yang lain seperti batu bara, emas, tembaga, dan bahan tambang lainnya.

\section{DAFTAR PUSTAKA}

Santosa Budi, 2011, Pemanfaatan Sistem Informasi Geografis Open Source Untuk Pelayanan Kesehatan Masyarakat di Yogyakarta, Jurnal Penelitian Dan Pengembangan Pemerintah Propinsi DIY, Vol III / No.4 / 2011

Sutarman, S.Kom., 2003, Membangun Aplikasi Web Dengan PHP dan MySQL, Garaha IImu, Yogyakarta.

Pressman, Roger S., 2002, "Software Engineering : A Pratitioner's Approach", Prentice Hall.

Prahasta, E, 2005, Sistem Informasi Geografis : Konsep-konsep Dasar, Informatika, Bandung.

Nuryadin, Ruslan, Ir., 2005, Panduan Menggunakan MapServer, Informatika, Bandung

HM. Jogiyanto, 2005, Analisis dan Desain Sistem Informasi Pendekatan Terstruktur, Penerbit Andi Offset, Yogyakarta. 